\title{
A Study on ELT High School Teachers' Practices to Foster Learner Autonomy
}

\author{
Mehmet Fatih Ürün \\ Department of Foreign Languages, Turkish Military Academy, Ankara, Turkey \\ Cennet Engin Demir \\ Department of Educational Sciences, Faculty of Education, Middle East Technical University, Ankara, Turkey \\ Hanife Akar \\ Department of Educational Sciences, Faculty of Education, Middle East Technical University, Ankara, Turkey
}

\begin{abstract}
The present study aims to identify the practices of ELT high school teachers to foster learner autonomy and to examine the differences with respect to the background variable of gender. The participants of the study were ELT high school teachers in the province of İzmir, Turkey $(N=118)$. Data were collected by means of Autonomy Practices Questionnaire, which is a structured quantitative and qualitative measure. The analysis revealed that ELT teachers are highly motivated to foster autonomy through some particular practices such as activity-based practices, material-based practices, student-centered practices, and objectivebased practices. Moreover, gender has significant effect on ELT teachers' student-centered practices to foster autonomy. The results were discussed with regard to real practices of ELT teachers and ELT curriculum implementation.
\end{abstract}

Index Terms - learner autonomy, English curriculum, practices to foster autonomy

\section{INTRODUCTION}

Gardner (2010) signified that there are more bilinguals in the world than monolinguals, and in more populated countries like China, India, and Nigeria, bilingualism is more of a requirement rather than an exception. English language teaching has definitely become one of the most demanding and crucial issues in many societies with technological and scientific developments, with improvements in international relations, in commercial accomplishments, and in transportation. These developmental changes have elicited a desire to learn about other cultures and nations, and with the concept of globalization, the importance of acquiring foreign languages (especially English) has been recognized by millions (Richards, 2006). Turkey is one of those places where educational issues have begun to attract people's attention as a result of competitive system of education and in this system the circumstances require students' acquisition of foreign languages autonomously to be able to have an important position in the society.

There is also a growing focus in the literature on the concept of autonomy in English language teaching (ELT), together with its obvious and hidden effects on the teaching process (Barfield \& Brown, 2007; Broady \& Kenning, 1996; Cotterall \& Crabbe, 1999; Little, Ridley, \& Ushioda, 2003). In general, the promotion of students' autonomy can be possible through helping students to identify their own goals, using effective strategies to achieve these goals, and creating consciousness of social contexts. (Inomata, 2008). Although there are responsibilities that belong to the teachers and the students, whether the students and the teachers are aware of the importance of the concept and of the possible ways to enhance language learning autonomy in the classroom context are some particular points that the recent research addresses.

According to constructivism which is tightly bound to learner autonomy, the students are encouraged to construct their own knowledge and fulfill their own learning needs and interests. The Ministry of National Education in Turkey have specified constructivist approach as a core element in foreign language teaching and even in the other fields such as classroom teaching and science teaching. Related to constructivist approach, Benson (2001) and Little (2007) indicated that learner autonomy is more than a skill of the learner. In essence, it is a product of a constant process of interaction between the learners and the teacher. Therefore, this study is necessary to investigate the products, in other words practices of the teachers, which constitute the interaction between the learners and the teacher to foster learner autonomy, rather than being concerned with students' and teachers' perceptions about learner autonomy.

As a supplementary method of constructivism in the ELT context, communicative language teaching has come into prominence. On this basis, some amendments related to ELT curriculum have been placed in light of the constructivist approach, in which learner-centeredness and learner autonomy are the spearheading factors, by the Ministry of National Education (MONE) in recent years. In 2007, the MONE in Turkey revised and restructured the National English Teaching Curriculum at the primary and secondary levels. According to this recent reform, CLT has been announced as the main base of the ELT curriculum, one of the main goals of which is described as to "develop written and oral 
communication skills of learners". Furthermore, this curriculum prescribes that "the main concern is the use of language as a means of communication rather than the rules of grammar, which is the traditional method". Subsequent to the adoption of the new CLT-based curriculum, MONE removed all the existing textbooks used in schools and replaced them with newly written course books based on the CLT approach. The present study provides English language teachers with useful resources to reflect on their own teaching through a structured quantitative and qualitative instrument. Secondly, two main implications for practice will be framed: promotion of autonomous learning environment and adjustments in ELT curriculum to promote autonomous learning.

\section{LITERATURE REVIEW}

\section{A. Theoretical Background}

At first, the theory of autonomy in language learning emerged as a result of research on the practice of adult selfdirected learning, which is characterized by Knowles (1975) (as cited in Benson, 2001). Self-directed learning seemed as a kind of basic element in adult education, since it was accepted to include a long-term period in which individuals agree to accept responsibility for all decisions related to their learning. In the 1970s and 1980s, this concept attracted considerable attention of the authorities, although it was not formally integrated into education.

It is important to state the fact that both autonomy and self-directed learning are concerned with teaching language learners first how to think, and then how to learn, and finally, how to take control of their own learning. At the same time, it can be beneficial to mention the trivial difference between autonomy and self-directed learning that was simply underlined by Dickinson (1987), indicating that self-directed learners accept responsibility for all the decisions related to the their learning, but not autonomously put those decisions into action; however, in autonomous learning, the learners both feel completely responsible for all the decisions concerned with their learning and the completion of these decisions.

\section{B. Definitions of Autonomy}

In literature, the common viewpoint about learner autonomy is that it emerges as a result of learners' approval of responsibility for their own learning (Benson \& Voller, 1997; Little, 1991; Dickinson, 1987). This means that autonomy requires the learner to develop control over his or her own learning and his or her own role in that process. According to Benson (2001), this control might take numerous forms for different individuals and even different forms for the same individual along with the contexts or time. For instance, the learner who shows a high degree of autonomy in one area can be non-autonomous in another.

Further definitions have emphasized that learner autonomy is not specific knowledge the learner has, but rather, a capacity that allows him or her to direct his or her own learning. For example, Little (1991) stated that "Autonomy is a capacity - for self-regulated learning, critical thinking, decision-making, and independent actions. Development of a particular kind of psychological relation to the process and content of his or her learning is a fundamental requirement".

\section{English Curriculum Implementation}

Nunan (1985) supported that English course designs, which are course syllabi, should comprise needs assessment, objective setting, selection of the learning resources and activities, language learning setting, and evaluation. However, learners' needs and expectations should be analyzed thoroughly because the general structure of the learner-centered approach necessitates the development of separate syllabi to satisfy different needs of the learners rather than the development of an entirely differentiated curriculum, which is impossible. Allwright (1986) also asserted that learners are confused about the learning objectives of language lessons because of the lack of communication between the learners and teachers. Therefore, teachers have the responsibility to explain the objectives as clearly as possible and to ask about the learners' opinions about the objectives as well.

On the other hand, Johnson (1989) added his opinions to Allwright's assertion and claimed that, first of all, language teachers should explicitly outline the objectives of their courses. Secondly, they should inquire about the possible contradictions between the perceptions of learners and teachers with regard to content and methodology. If there are, negotiations should be made to find solutions. Thirdly, modifications related to the implementation of on-going course should be conducted.

\section{Research Studies Conducted in Turkey on Learner Autonomy in Language Teaching}

In their study, Bozpolat and Gömleksiz (2011) aimed to investigate the opinions of sixth grade students at elementary schools in Sivas, Turkey with regard to learner autonomy in foreign language learning. They made use of the descriptive research method through a questionnaire applied to 975 elementary school students selected randomly in Sivas city center in the spring term of the 2010-2011 academic year. The results of the study indicated that in terms of readiness for self-direction, studying independently in language learning, and of the classifications of selecting content and assessment, and motivation, female students were more successful. However, there was no significant difference found among the students' views about the importance of the teacher, the role of the teacher as a supervisor, about the objectives of the lesson, language learning activities, and evaluation and interaction with other cultures sub-scales in terms of the gender variable. 
Balçıkanlı (2008) conducted a study that aimed to foster learner autonomy through activities at the Preparatory School of Gazi University. In order to achieve this goal, two classes were selected randomly, each of which consisted of twenty learners studying English from several faculties at Gazi University, as an experimental group and a control group. Before implementation, a learner autonomy questionnaire, consisting of three parts, was administered to both groups to reveal possible levels of autonomy they possessed. While the experimental group was instructed in the autonomy implementation, the control group continued their education without any alteration. After the 12-week implementation process, the same questionnaire was administered to both groups once again. At the end of the process, the statistical results were analyzed and interpreted. The results showed that the learners in the experimental group scored higher than those in the control group and the experimental group had a strong tendency towards autonomy compared to the control group with a few exceptions. According to the results, it was concluded that the syllabi of the preparatory schools should be restructured in parallel with the principles of learner autonomy. It was also decided that the course books that were used at preparatory schools should be evaluated as to whether they encourage autonomy or not, in-service training for teachers should be provided, and as a final point, self-access laboratories should be developed technically to make best of them.

\section{E. Research Studies Conducted in Other Countries on Learner Autonomy in Language Teaching}

Haseborg (2012) conducted a participatory research study to contribute to the experimental knowledge base of autonomy to help fill some of the gaps in the body of research pursuing the answers to the questions such as, "How do students perceive the ability to make autonomous learning choices?", " How does the ability to make autonomous choices regarding format, content, and timing affect motivation?", and "Which areas of language learning most benefit from autonomous learning choices?". The data were collected by means of two surveys, a learning journal kept by each participant in the study and completed for every work cycle, and reflective statements of the participants. The findings of the study indicated that it is also in the interest of the teacher to provide a well-structured learning environment. At the same time, many students also reported that their skills improved in terms of communication and in the areas of reading, writing, listening, and speaking. Lastly, it was realized that the choices made in relation to projects to improve the four skills benefited the students' self-confidence and helped them progress their ability to communicate in German.

Benson (2010) conducted a collective case study of four Hong Kong secondary school teachers' experiences with regard to obstructions to the development of teacher autonomy in English language teaching, and their implications for teacher education. The study was designed as an interview-based study and the participants were four English teachers approaching the end of a two-year part-time MA in Applied Linguistics program at a university in Hong Kong. The findings of the study suggested that the constraints were systemic and primarily focused around 'Schemes of Work', school-based regulations, and the supervision system. On the other hand, participant teachers were able to create spaces for teacher autonomy, but the nature of these spaces was developed according to the school context and partly through previous educational experiences as either learners or teachers. Through the study, it was also concluded that the impact of teacher education courses that depend on experimentation with new ideas in the classroom tend to be inadequate in many state school systems and language teacher education may benefit from a teachers' practices employed with great passion to perform their professions.

In Norwegian secondary schools, Trebbi (2003) performed a study to compare the traditional curriculum with an experience-oriented curriculum, which enables the learners to control their own language learning and flexible goal setting. Further aims of the project were to "promote students' insight into what it is to learn French/German and the advancement of their capacity to take charge of their own learning" (Trebbi, p. 172). Trebbi also stated that five years after the implementation of the new curriculum, some of the teachers showed the constraints of rejection, but rearranging the traditional concepts and innovative approaches were also observed. Additionally, it was realized that it is very difficult to implement principles of learner autonomy on a curricular level.

Camilleri (1999)'s study included questionnaire of classroom activities data collected from 328 teachers in six European contexts (Malta, The Netherlands, Belorussia, Poland, Estonia, and Slovenia) and consisted of 13 items each asking about the extent to which learners, according to the teachers, should be involved in decisions about a range of learning activities, such as establishing the objectives of a course or selecting course content. In the Maltese context, although it was difficult to define how much they were aware of the autonomy concept, teachers' views, based on classroom experience, were positive because teachers displayed their willingness to care about learners' decisions about their learning strategies and content and these factors' positive effects on the outcome of language teaching process.

\section{METHODOLOGY}

\section{A. Research Questions}

The study aims to answer the following research questions:

1. How do ELT high school teachers foster learner autonomy in their classes?

1a. Which practices do ELT high school teachers use to foster learner autonomy?

1b. Do male and female teachers differ in their practices while fostering autonomy?

2. What are ELT high school teachers' strengths with regard to fostering learner autonomy through ELT curriculum in their classes? 
3. What are ELT high school teachers' needs with regard to fostering learner autonomy through ELT curriculum in their classes?

4. What are ELT high school teachers' suggestions with regard to fostering learner autonomy through ELT curriculum in their classes?

The data collection instrument was cross-sectional, which means that it was administered at one specific point in time. Both quantitative and qualitative data necessary to answer the research questions in this survey study were collected through a structured questionnaire developed by the researchers. The aim was to identify ELT high school teachers' practices to foster learner autonomy during their classes with regard to four categories of curriculum implementation: (1) determining objectives, (2) determining the content, (3) planning for the instructional process, and (4) evaluation. Moreover, ELT high school teachers' opinions were examined about their strengths, needs, and their suggestions to the stakeholders from the perspective of the challenges they encounter with regard to objectives, activities, materials, and evaluation while developing an autonomous learning environment. Descriptive and inferential analyses were conducted to obtain a deeper insight into the research questions that were used in this study (Table I).

TABLE I.

OVERALL RESEARCH DESIGN

\begin{tabular}{|l|l|}
\hline 1. Research Questions & $\begin{array}{l}\text { • Literature Review } \\
\bullet \text { Previous studies }\end{array}$ \\
\hline 2. Sampling & $\bullet$ Convenience Sampling \\
\hline 3. Research Design & $\bullet$ Cross-sectional Survey Design \\
\hline 4. Instrument & $\begin{array}{l}\bullet \text { Questionnaire constructed by } \\
\text { the researchers }\end{array}$ \\
\hline 5. Data Collection Procedure & $\begin{array}{l}\text { - Administration of the } \\
\text { questionnaire to 118 high school } \\
\text { ELT teachers in their school } \\
\text { settings within 20 minutes }\end{array}$ \\
\hline 6. Data Analysis Procedure & $\begin{array}{l}\bullet \text { SPSS software program for } \\
\text { descriptive and inferential } \\
\text { statistics }\end{array}$ \\
\hline 7. Interpreting the Results & $\begin{array}{l}\text { - Relevant literature and the } \\
\text { context of the present study }\end{array}$ \\
\hline
\end{tabular}

\section{B. Participants}

The target population of the study included all ELT high school teachers serving at the 9-12 grade levels (15-18 years old students) and implementing high school ELT curriculum in both public and private schools in İzmir, Turkey. İzmir is the third biggest province in Turkey and it's famous for its citizens' great interests in educational issues. There were 2801 ELT high school teachers in İzmir. The accessible population of this study, due to its convenience, consisted of 118 high school ELT teachers from 18 different high schools in different parts of the city; therefore, the socio-economic status of the setting was relatively better than other cities in Turkey. 136 ELT teachers were sampled in this study. In total, 118 of them returned the questionnaires which resulted in a response rate of $87 \%$. Among participant ELT teachers $(N=118), 56 \%(n=66)$ of them were female, whereas $44 \%(n=52)$ of them were male. The participant teachers were definitely well-trained ones because they were supposed to pass several vocational examinations after graduation to take up an appointment and İzmir is known to be a city which is very difficult to be appointed as an English teacher because of its positive attributes in terms of an ideal educational environment.

\section{Instrument}

In the present study, a three part questionnaire was developed by the researchers through investigating relevant research studies because there were no research studies that specifically aimed to explore teachers' practices to foster learner autonomy in English language teaching. The first part aimed to collect data about the demographic characteristics of the participants including several background variables, such as age, gender, academic status, graduation department, vocational status, serving at a state or private school, type of the school, duration in the profession, the number of classes taught, number of the students taught, the number of the teaching hours in a week, ELT course book they use, the number of the in-service training programs they attended in the last 3 years, and name of these in-service training programs(see Appendix A). The second portion, which consisted of a 32-item, 5-point Likert scale, measuring 5 for "always", 4 for "often", 3 for "sometimes", 2 for "rarely", and 1 for "never", was developed to measure the frequency of the practices of ELT high school teachers to enhance learner autonomy in their classes. The rating for the scale was from always to never. The items in this section aimed to measure ELT high school teachers' practices foster learner autonomy during their classes with regard to four categories of curriculum implementation: (1) determining objectives, (2) determining the content, (3) planning for the instructional process, and (4) evaluation. The third part included 4 open-ended questions to collect qualitative data through the questions based on their strengths, needs, suggestions, and extra information related to objectives, activities, materials, evaluation with regard to developing an autonomous learning environment. 


\section{Data Analysis}

The data were analyzed using descriptive and inferential statistics. Factor analysis was used as a data reduction and classification method (see Appendix B). Principal component analysis with a varimax rotation was carried out to identify clusters of variables. One-Way Repeated Measures of Analysis of Variance was conducted to compare the dimensions of the practices that ELT high school teachers implement to foster autonomy. A Multivariate Analysis of Variance (MANOVA) was conducted to examine the differences in the dimensions of the practices with respect to the background variable of gender. The .05 level was established as a criterion of statistical significance for all the statistical procedures that were performed.

In order to analyze the open-ended data obtained through 4 questions at the end of the questionnaire, the data were firstly coded under predetermined themes with regard to research questions and the closed-ended items of the questionnaire. The codes under each theme were identified according to the predetermined themes and the coded data were subjected to content analysis. Based on the frequencies and percentages, some responses that were explanatory of the quantitative data were reported.

\section{RESULTS}

\section{A. Results Concerning the Dimensions of Practices to Foster Autonomy}

In the ELT high school teachers' practices questionnaire used in this study, dimensions were related to the "ELT activities practiced by the teachers", "practices used by the teachers to foster learner autonomy through the use of information and communication technologies", "practices to enhance learner autonomy through informing them about their own responsibilities in English language acquisition", and " practices to enhance learner autonomy through informing them about the general objectives of the English classes".

Kaiser-Meyer-Olkin (KMO) and Bartlett's test indicated sampling adequacy for factor analysis. The KMO measure was 0.721 and also Bartlett's test of sphericity (.00) was significant. Initial principal component analysis with varimax rotation of the 32 items inventory revealed ten factors with eigenvalues greater than one. However, results of the inventory in terms of the variety of the loadings indicated that four factors should be examined since they had large loadings and defined most of the items.

Initial principal component analysis calling for four factors was conducted. In four-factor structure, four items (Items $10,21,23,29)$ were omitted since they weren't loaded heavily on these factors. After deleting the four items, subsequent factor analysis for the refinement of the four-factor structure retained items weighted highly on their own scale. These four dimensions explained $44 \%$ of variance. "Activity-Based Practices" subscale pertained 14 items. On the other hand, "Material-Based Practices" subscale pertained 5 items while "Student-centered Practices" subscale pertained again 5 items. Lastly, "Objective-Based Practices" subscale pertained 4 items. Moreover, overall reliability test was conducted and value of Cronbach's Alpha was satisfying as: $\alpha=.83$

Next, items clustered within each dimension were examined in terms of their content. The investigation of item content revealed that items loaded meaningfully into dimensions. These dimensions were named as (1) activity-based practices, (2) material-based practices, (3) student-centered practices and (4) objective-based practices.

\section{B. Results Concerning the Difference among Dimensions of ELT High School Teachers' Practices to Foster Autonomy}

A one-way repeated measure analysis of variance (ANOVA) was conducted to determine if significant mean differences existed among these dimensions. The dimensions of ELT teachers' practices for fostering learner autonomy as most frequently and least frequently were examined.

To begin with the sphericity assumption of repeated measures ANOVA, Mauchly's test was conducted. Sphericity assumption indicated the equality of variances of the distinctions between dimensions (Field, 2005). Mauchly's test (.001) indicated that the assumption of sphericity had been violated $\left(\chi^{2}(5)=20.922, p<.05\right)$, therefore degrees of freedom were corrected using Greenhouse-Geisser estimates of sphericity $(\varepsilon=.89)$ because the data was accepted spherical and the variances of differences were accepted to be homogenous if that $\varepsilon$ is closer to 1.00 (Field, 2005). For that reason, it could be concluded that the data did not embody a deviation from sphericity (Table II).

TABLE II.

MEANS AND STANDARD DEVIATIONS FOR FOUR FACTORS

\begin{tabular}{lll}
\hline Dimensions & Mean & SD \\
\hline Activity-based Practices & 3.77 & .48 \\
Material-based Practices & 3.82 & .73 \\
Student-centered Practices & 3.81 & .60 \\
Objective-based Practices & 4.32 & .49 \\
\hline
\end{tabular}

After that, repeated contrast test was used to determine priorities and to answer the research question of which practices ELT high school teachers use to foster learner autonomy. According to the results, there was a significant mean difference only between student-centered practices dimension and objective-based practices dimension $[\mathrm{F}(1,117)$ $=65.529, \mathrm{p}<.05$, partial $\eta^{2}=.359$ ] (Table III). 
TABLE III.

REPEATED CONTRASTS OF THE DIMENSIONS

\begin{tabular}{|c|c|c|c|c|}
\hline $\begin{array}{l}\text { Practice } \\
\text { Dimensions } \\
\end{array}$ & df & $\bar{F}$ & $P$ & $\eta^{2}$ \\
\hline AP vs. MP & 1 & .782 & .37 & .007 \\
\hline MP vs. SP & 1 & .029 & .86 & .000 \\
\hline SP vs. OP & 1 & 65.529 & .00 & .359 \\
\hline
\end{tabular}

Repeated measures ANOVA revealed a significant overall difference among the means of 4 dimensions. A follow-up pairwise comparison was conducted to examine carefully the mean differences among dimensions. There was a significant mean difference between objective based practices dimension and each of the other dimensions (Table IV). Namely, the mean differences between OP-AP, OP-MP, and OP-SP were significant at the $\mathrm{p}<.05$ while there were no significant differences between the other pairs (AP-MP, AP-SP, MP-SP).

TABLE IV.

PAİRWISE COMPARISONS OF THE ACTIVITY-BASED, MATERİAL-BASED, STUDENT-CENTERED, OBJECTIVE-BASED PRACTICES FACTORS

\begin{tabular}{|c|c|c|c|c|}
\hline (1) Practices & (J) Practices & Mean Difference (I-J) & SD & $P$ \\
\hline \multirow[t]{3}{*}{ Activity-based Practices } & Material-based Practices & -.057 & .064 & 1.00 \\
\hline & Student-centered Practices & -.043 & .065 & 1.00 \\
\hline & Objective-based Practices & -.551 & .056 & .00 \\
\hline \multirow[t]{3}{*}{ Material-based Practices } & Activity-based Practices & .057 & .06 & 1.00 \\
\hline & Student-centered Practices & .014 & .079 & 1.00 \\
\hline & Objective-based Practices & -.495 & .074 & .00 \\
\hline \multirow[t]{3}{*}{ Student-centered Practices } & Activity-based Practices & .043 & .06 & 1.00 \\
\hline & Material-based Practices & -.014 & .079 & 1.00 \\
\hline & Objective-based Practices & -.508 & .063 & .00 \\
\hline \multirow[t]{3}{*}{ Objective-based Practices } & Activity-based Practices & .551 & .056 & .00 \\
\hline & Material-based Practices & .495 & .074 & .00 \\
\hline & Student-centered Practices & .508 & .06 & .00 \\
\hline
\end{tabular}

\section{Results Concerning the Difference among Perceived Dimensions of Autonomy Practices with Respect to Certain Background Variables}

\section{1) Gender}

A one-way MANOVA was conducted to find out whether there is any significant mean difference among the dimensions of ELT high school teachers' practices to foster learner autonomy with respect to gender. This analysis disclosed that gender difference had no significant effect on the dimensions of fostering autonomy [Wilk's $\lambda=.94, \mathrm{~F}$ $(4,113)=1.84, p<.05$, partial $\left.\eta^{2}=.06\right]$. Table V shows the means and standard deviations of the dimensions of fostering autonomy with respect to the gender.

Analysis of variance (ANOVA) on each dependent variable was conducted as follow-up tests to the MANOVA. The univariate tests indicated non-significant differences between male and female teachers on 3 dimensions of fostering autonomy: activity-based practices $\left[\mathrm{F}(1,116)=.026, \mathrm{p}<.05\right.$, partial $\left.\eta^{2}=.000\right]$, material-based practices $[\mathrm{F}(1,116)=$ $.928, \mathrm{p}<.05$, partial $\left.\eta^{2}=.008\right]$, and thirdly objective-based practices $\left[\mathrm{F}(1,116)=.000, \mathrm{p}<.05\right.$, partial $\left.\eta^{2}=.000\right]$. On the other hand, the univariate tests revealed significant difference between male and female teachers on student-centered dimension of fostering autonomy $\left[\mathrm{F}(1,116)=6.466, \mathrm{p}<.05\right.$, partial $\left.\eta^{2}=.053\right]$. Consistent with the results of univariate tests, comparison between means of female and male teachers revealed that mean differences were non-significant for all dimensions of fostering autonomy except student-centered practices dimension which was significant (Table VI).

TABle V.

The Means and STANDARd Deviations of THE Dimensions of Fostering Autonomy with ReSPECT TO THE GENDER

\begin{tabular}{llll}
\hline Dimensions & Gender & Mean & SD \\
\hline Activity-based Practices & Female & 3.78 & .55 \\
& Male & 3.76 & .39 \\
Material-based Practices & Female & 3.88 & .68 \\
& Male & 3.75 & .79 \\
\multirow{2}{*}{ Student-centered Practices } & Female & 3.93 & .57 \\
& Male & 3.65 & .61 \\
\multirow{2}{*}{ Objective-based Practices } & Female & 4.32 & .55 \\
& Male & 4.32 & .42 \\
\hline
\end{tabular}


TABLE VI.

COMPARISONS OF MEANS OF FEMALE AND MALE ELT HİGH SCHOOL TEACHERS ON Four DimensínNS

\begin{tabular}{|c|c|c|c|c|}
\hline Dimension & (I)Gender & (J)Gender & Mean Difference (I-J) & $P$ \\
\hline \multirow[t]{2}{*}{ Activity-based Practices } & Female & Male & .015 & .872 \\
\hline & Male & Female & -.015 & .872 \\
\hline \multirow[t]{2}{*}{ Material-based Practices } & Female & Male & .131 & .337 \\
\hline & Male & Female & -.131 & .337 \\
\hline \multirow{2}{*}{ Student-centered Practices } & Female & Male & $.279(*)$ & .01 \\
\hline & Male & Female & $-.279(*)$ & .01 \\
\hline \multirow[t]{2}{*}{ Objective-based Practices } & Female & Male & .000 & .999 \\
\hline & Male & Female & .000 & .999 \\
\hline
\end{tabular}

\section{Results Concerning the Qualitative Data}

Parallel to the quantitative data, most of the participant teachers indicated that they found themselves capable of implementing activity-based practices to foster learner autonomy in their classes via involving the students in the process of determining activities, using different and attractive activities in the classes, assigning projects and making use of technology in their classes.

Among all, 82 of the participants shared their opinions with regard to their needs while fostering learner autonomy and $37 \%(n=30)$ of the respondent teachers signified that they face with students' motivation problems and this might hinder improvement of language learning autonomy in their classes. At the same time, lack of technological devices and necessary materials are other two important factors that affect autonomy in English classes according to 25 ELT teachers $(30 \%)$.

Among all, 70 of the participants shared their opinions with regard to their suggestions while fostering learner autonomy and 37\% ( $n=26)$ of them expressed the importance information and communication technologies in English classes and 22 of them $(32 \%)$ highlighted that course books should have supplementary materials used by means of technology to be able to implement some particular techniques such as audio-visual materials for listening or interactive modules for reading activities for the enhancement of language learning autonomy in their classes.

\section{CONCLUSIONS}

As parallel to the findings of Yahong (2009)'s research study through classroom observations, her own journal, her students' journals, and through interviewing with them, substantial percentage of the ELT high school teachers in this study remarked that they frequently offer variety in class activities via considering different learning styles of their students, make use of activities related to daily lives of them, use activities that will contribute to social progress of their students, and lastly give them various responsibilities (board arrangement, today's proverb, phonetics, important events, etc.) of in-class and out-of-class activities.

Although the results in the present study indicated that there was a significant difference among the means of 4 dimensions of ELT teachers' practices for fostering learner autonomy, the greatest mean difference was determined between student-centered practices dimension and objective-based practices dimension according to the repeated contrast test. This indicates that ELT high school teachers give more importance to objective-based practices than the other dimensions of practices. On the other hand, as the data did not embody a deviation from sphericity $(\varepsilon=.89)$, it can be concluded that fostering learner autonomy is highly affected by the dimensions of practices ELT high school teachers use to foster autonomy in their classes. The findings of the study of Nakata (2011) showed that many Japanese EFL high school teachers got the importance of autonomy, but they were not completely ready to promote it. However, ELT high school teachers in İzmir seemed to have acquired the importance of autonomy and also they had assumedly started to promote it.

The results indicated that gender has non-significant effect on 3 of the dimensions of practices which are activitybased practices, material-based practices, and thirdly objective-based practices. On the other hand, the univariate tests revealed significant difference between male and female teachers on student-centered dimension of fostering autonomy. According to the findings, compared to male ELT high school teachers, female teachers implement student-centered practices to be able to enhance learner autonomy in their classes. This might be because of the authoritarian nature of the male teachers who resist to accepting the evolving English language teaching environment which puts the students into the center in consideration of constructivism. This difference between males and female might be valid for this dimension because other dimensions were not directly bound to the human nature as much as student-centered dimension of fostering autonomy. Therefore, the findings also indicated that female and male teachers equally made use of the other three dimensions of practices to foster autonomy in their classes. Related to this finding, Evrekli, Şaşmaz-Ören, and İnel (2010) conducted a survey design study and examined student teachers' self-efficacy levels for implementing the constructivist approach in terms of gender. In terms of implementing constructive theories in the classroom, the result was found to be in favor of the female student teachers similar to the finding of the current study. 
Majority of the respondents indicated positive attributes to foster learner autonomy and to develop autonomous learning environment in their classes. The strengths which were stated entirely supported the findings related to the closed-ended items in the questionnaire and provided implications about how eagerly ELT high school teachers foster learner autonomy in their classrooms.

Although the participant ELT teachers mentioned their intensive use of practices with regard to fostering learner autonomy in their classes while developing an autonomous learning environment, important number of them signified that there might be negative influences related to the learners themselves and the context in which they aim to improve autonomous language learning such as lacks of technological devices and authentic materials.

Findings of the ELT high school teachers' suggestions with regard to fostering learner autonomy in their classes while developing an autonomous learning environment revealed that they have high motivation towards promotion of learner autonomy and attempt to produce solutions for the development of autonomous learning environment as parallel with the findings of the quantitative data.

Most frequently stated solutions were:

(1) Information and communication technology must be provided in English classrooms.

(2) Course books should be improved by the experts and supplemented by interactive CDs.

(3) Motivation of the students towards learning English should be enhanced.

\section{IMPLICATIIONS FOR PRACTICE}

The findings of the study according to the quantitative data indicated that the dimensions of the practices to foster learner autonomy in English classes are totally parallel to the four elements of curriculum implementation process as previously mentioned and these four dimensions are almost equally used by ELT high school teachers to a considerable extent. However, objective-based practices are implemented more than the other types of practices to foster autonomy as a result of a paired comparison. Another significant result was that female ELT high school teachers give more importance to the student-centered practices more than males do to be able to foster learner autonomy in their classes. This finding was interrelated to the reason stemming from the authoritarian nature of the male teachers which also implies the motherly nature of the female teachers that puts the students into the center.

On the other hand, qualitative data indicated that ELT high school teachers have a contributive approach towards the enhancement of learner autonomy and also have lots of problems stemming from motivation level of the students, lack of capabilities of the language learning environments, and teacher-administration-headquarters relations.

The design of the study made it possible for the researchers to consider two main implications for practice: promotion of autonomous learning environment and adjustments in ELT curriculum to promote autonomous learning. In the process of fostering learner autonomy in language learning, learner choice is essential. In consequence, developing an autonomous learning environment, which provides students with opportunities to make decisions on the objectives and content of the lesson, plan, observe, and evaluate their learning process.

At this point, language learning context is very important and it is supposed to employ all the constituents such as curriculum, administration, teachers, learners, resources, effectively and in an ideal order. For instance, Dörnyei (1998) identified inadequate school facilities such as too big groups of classes and frequent change of teachers as demotivating factors in language learning environment. At the same time, ELT teachers identified some other problems that hinder fostering learner autonomy in their classes as: (1) lack of information and communication technology in English classes, (2) demotivating approach of the administration towards development of autonomous learning environment, (3) inefficiency of the course books, (4) lack of motivation of the students towards English language teaching, etc. Together with the other problems mentioned before, all the hindrances deriving from external factors to the development of autonomous learning environment should be minimized through collaborative works of the stakeholders.

As stated by Benson (2001) there has been positive consequences of the experiments in which the learner was encouraged to take a certain amount of control over the planning and assessment of classroom learning and these experiments have also shown that learners are able to exercise control over these aspects of their learning on condition that they are provided with the opportunity to do so together with the necessary guidance. According to the major findings of this study, it was identified that ELT high school teachers put their objectives into practice with regard to development of autonomous language learning environment in their classroom settings in spite of external obstructions. On the other hand, they have many expectations to improvement of conditions in general to be able to achieve their aims related to effective teaching of English language. These expectations should be shared by the curricularists, administrators, learners, and even by the parents as well.

Furthermore, ELT high school teachers in this study described their particular strengths to form an autonomous language learning environment such as inclusion of the students into the process of determining objectives of the lesson, making use of contemporary language teaching methods and techniques which are beneficial for the improvement of metacognitive skills of the students, and utilizing variety of activities and resources according to different learning styles of the students to be able to promote their motivation towards learning English language. These strengths of the teachers are important since they indicate that the on-going circumstances in ELT classrooms are on behalf of the improvement of an autonomous learning environment. Thus, in-service training programs can be very beneficial for 
fostering autonomy in language learning through informing the ELT teachers about the most effective strategies to foster autonomy and technology use in language teaching.

Thirdly, the participant ELT teachers' needs to develop autonomous learning environment and their suggestions to improve the concept should be taken into consideration by the authorities and necessary amendments should be put into practice. For instance, as a new approach to foreign language learning and foreign language teaching, autonomous learning highlights the learners' individual and social awareness of the learning process. Accordingly, the curricularists will need to re-examine the course objectives, course designs, language learning materials, and supplementary resources with the aim of fostering autonomous learning. Acting upon the analysis, research will be conducted to find out the basic principles and aspects of autonomous learning from the perspectives of both teachers and students through observation or action research. After that, discussions will be held to determine what could be done in accordance with the data obtained from the teachers. As a result, these stages will be integrated into curriculum development.

\section{IMPLICATIONS FOR FURTHER RESEARCH}

In this part recommendations for future researchers are presented.

1. In the present study the data were gathered only from ELT high school teachers, a further study can be carried out via collecting data from ELT elementary school teachers or from the teachers at both levels, which might give a better idea for the curriculum members when designing new programs to develop autonomous learning.

2. A further research can be conducted as a case study in school settings by which researchers can gather data from various data sources such as biographical or end-of-course questionnaires, needs analysis, student diaries and portfolios. In this way, a more detailed depiction of how learners receive autonomous language learning strategies and develop their decision-making skills of objectives, activities, materials, and evaluation can be examined.

3. A further research can be conducted as a case study in school settings by which researchers can gather data through their observations of the practices which are indicated to be done by ELT high school teachers with regard to fostering learner autonomy while developing an autonomous learning environment.

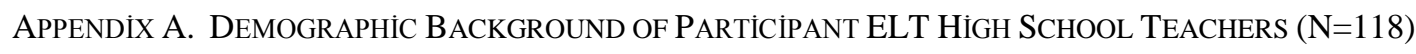

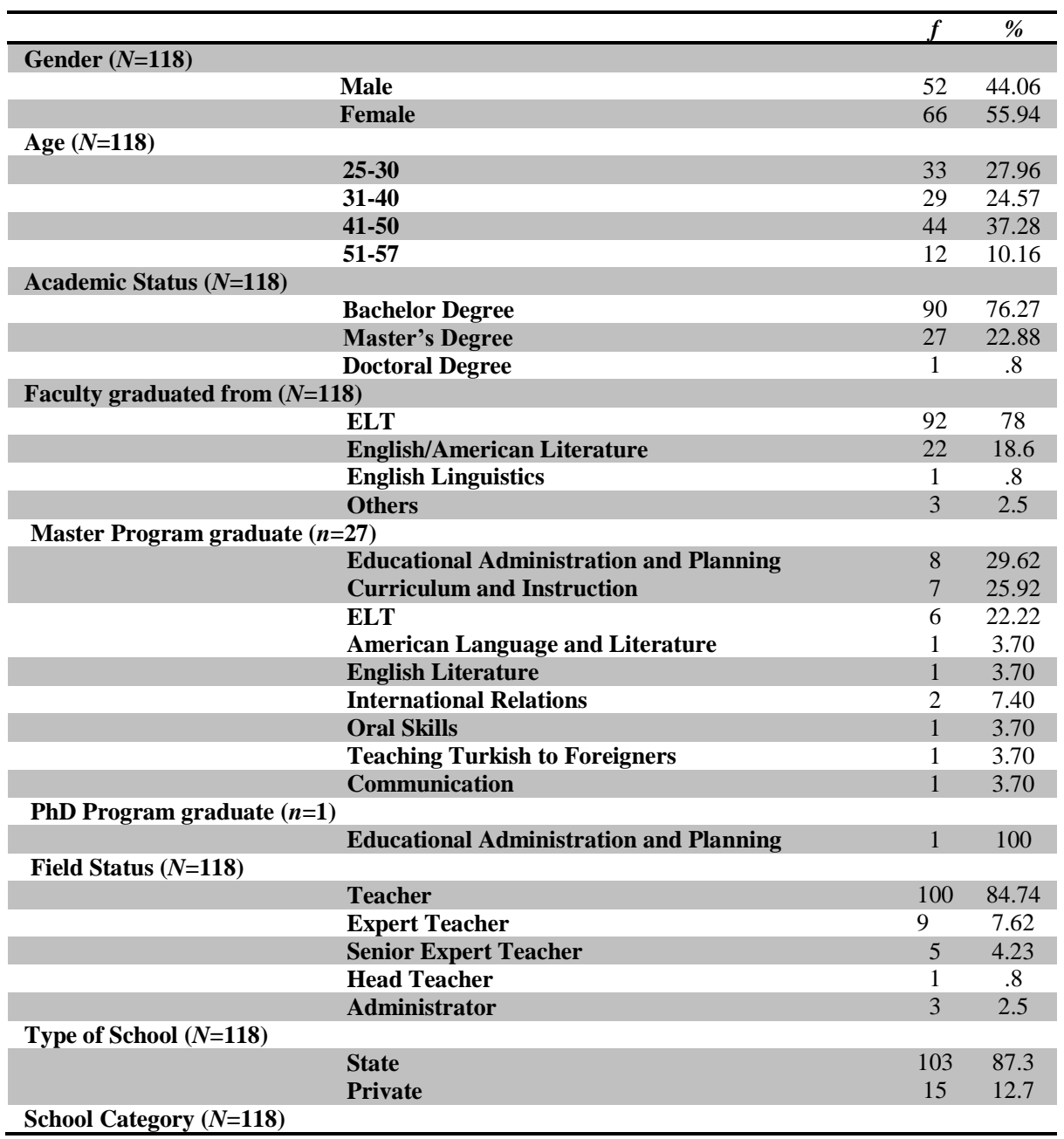




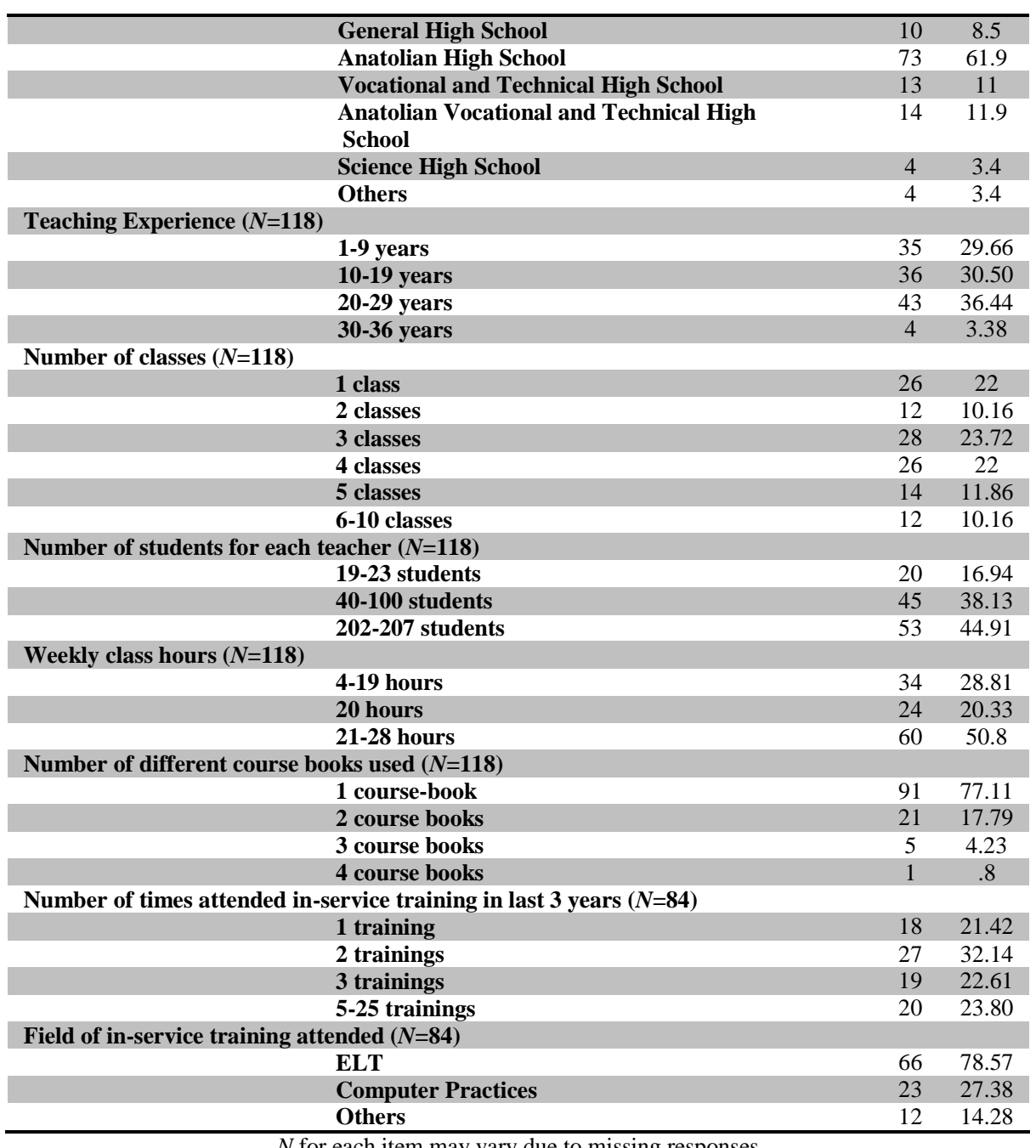

$N$ for each item may vary due to missing responses

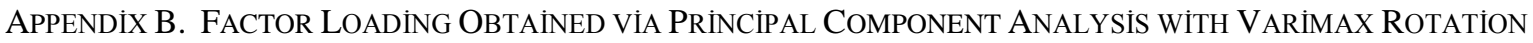

\begin{tabular}{|c|c|c|c|c|}
\hline Items of the Questionnaire & D1 & D2 & D3 & D4 \\
\hline $\begin{array}{l}\text { 16. I use different activities to my students' enhancement } \\
\text { of time management in my classes. }\end{array}$ & .700 & .173 & .253 & .025 \\
\hline $\begin{array}{l}\text { 9. I assign individual projects (poster, brochure, essay, } \\
\text { presentation, etc.) to my students. }\end{array}$ & .642 & .115 & -.081 & .209 \\
\hline $\begin{array}{l}\text { 12. I make my students do groupwork as out-of-class } \\
\text { activities. }\end{array}$ & .611 & .027 & 190 & -.118 \\
\hline $\begin{array}{l}\text { 19. I use activities that will contribute to social progress } \\
\text { of my students. }\end{array}$ & .597 & .346 & -.018 & -.124 \\
\hline $\begin{array}{l}\text { 31. I regularly have private talks with my students for } \\
\text { the evaluation of their own academic progression. }\end{array}$ & .589 & -.027 & .055 & .189 \\
\hline $\begin{array}{l}\text { 22. I give my students various responsibilities (board } \\
\text { arrangement, today's proverb, phonetics, important } \\
\text { events, etc.) of in-class and out-of-class activities. }\end{array}$ & .551 & -.088 & -.212 & .113 \\
\hline $\begin{array}{l}\text { 14. I make adaptations to foster learner autonomy by } \\
\text { using different activities in my classes. }\end{array}$ & .535 & .172 & .211 & .075 \\
\hline $\begin{array}{l}\text { 11. I make my students do groupwork as in-class } \\
\text { activities. }\end{array}$ & .526 & .036 & -.193 & -.113 \\
\hline 30. I make use of peer evaluation in class activities. & .506 & -.011 & -.077 & .222 \\
\hline 13. I make my students have their own portfolio. & .490 & .137 & .117 & -.077 \\
\hline $\begin{array}{l}\text { 17. I offer variety in class activities via considering } \\
\text { different learning styles of my students. }\end{array}$ & .487 & .306 & .031 & .098 \\
\hline $\begin{array}{l}\text { 15. I encourage my students to make their own } \\
\text { interpretations in class activities. }\end{array}$ & .473 & .195 & .337 & .115 \\
\hline $\begin{array}{l}\text { 7. I involve my students in the process of determining } \\
\text { in-class activities. }\end{array}$ & .465 & .097 & .268 & -.011 \\
\hline $\begin{array}{l}\text { 18. I use activities that are related to daily lives of my } \\
\text { students. }\end{array}$ & .416 & .403 & .011 & -.143 \\
\hline
\end{tabular}




\begin{tabular}{|c|c|c|c|c|}
\hline $\begin{array}{l}\text { 26. I use information and communication technology } \\
\text { (computer, internet, delineascope, etc.) effectively } \\
\text { in my classes. }\end{array}$ & -.054 & .859 & .067 & .067 \\
\hline $\begin{array}{l}\text { 27. I establish an environment in which my students use } \\
\text { information and communication technology } \\
\text { (computer, internet, delineascope, etc.). }\end{array}$ & -.004 & .769 & .052 & .111 \\
\hline $\begin{array}{l}\text { 28. I encourage my students to use information and } \\
\text { communication technology (computer, internet, } \\
\text { delineascope, etc.) outside the class. }\end{array}$ & .221 & .578 & -.009 & .187 \\
\hline $\begin{array}{l}\text { 20. I use activities that will contribute to cultural } \\
\text { development of my students. }\end{array}$ & .391 & .524 & .204 & -.263 \\
\hline $\begin{array}{l}\text { 25. I prepare authentic materials according to the } \\
\text { observable needs of the students. }\end{array}$ & .322 & .499 & .059 & .166 \\
\hline $\begin{array}{l}\text { 4. I encourage my students to determine their own } \\
\text { needs for the acquisition of English Language. }\end{array}$ & .019 & .009 & .756 & -.068 \\
\hline $\begin{array}{l}\text { 5. I encourage my students to determine their own } \\
\text { learning styles for the acquisition of English Language. }\end{array}$ & .096 & -.042 & .738 & -.040 \\
\hline 3. I encourage my students to set their own objectives. & -.064 & .066 & .624 & .405 \\
\hline $\begin{array}{l}\text { 6. I encourage my students to determine contents they } \\
\text { need to learn for the acquisition of English Language. }\end{array}$ & -.003 & .096 & .606 & .185 \\
\hline $\begin{array}{l}\text { 2. I take my students' opinions into consideration while } \\
\text { determining objectives of the lesson. }\end{array}$ & .118 & .060 & .516 & .070 \\
\hline $\begin{array}{l}\text { 1. I clearly explain the general objectives of the lesson } \\
\text { at the beginning of the term. }\end{array}$ & .012 & .038 & .087 & .743 \\
\hline $\begin{array}{l}\text { 8. I emphasize that the responsibility of learning } \\
\text { belongs to the students themselves in my classes. }\end{array}$ & -.040 & -.017 & .178 & .724 \\
\hline $\begin{array}{l}\text { 32. I inform my students about the fact that the } \\
\text { teaching process of the lesson is interoperated } \\
\text { among parents, colleagues, administrators, and students. }\end{array}$ & .348 & .070 & .059 & .577 \\
\hline $\begin{array}{l}\text { 24. I guide my students to get the most out of the } \\
\text { course book. }\end{array}$ & .096 & .240 & .003 & .536 \\
\hline
\end{tabular}

\section{ACKNOWLEDGMENT}

We place on record, our sincere gratitude to Assist. Prof. Dr. Nurdan Gürbüz and Assist. Prof. Dr. Gökçe Gökalp for their constructive feedback and encouragement they provided throughout the seminar.

\section{REFERENCES}

[1] Allwright, R.L. (1986). Making sense of instruction: what's the problem? PALM, 1, 2. University of Michigan.

[2] Barfield, A., \& Brown, S. H. (Eds.) (2007). Reconstructing autonomy in language education. New York, NY: Palgrave Macmillan.

[3] Balçıkanl1, C. (2010). Learner autonomy in language learning: Student teachers' beliefs. Australian Journal of Teacher Education, 35(1), 90-103. Retrieved January 20, 2013, from http://websitem.gazi.edu.tr/site/balcikanli/files/download/id/6672

[4] Benson, P. (2010). Measuring autonomy: Should we put our ability to the test? In A. Paran \& L. Sercu (Eds.), Testing the untestable in language education (pp. 77-97). Bristol, UK: Multilingual Matters.

[5] Benson, P. (2001). Teaching and researching autonomy in language learning. Harlow, England: Longman.

[6] Benson, P. (1997). The philosophy and politics of learner autonomy. In P. Benson \& P. Voller (Eds.), Autonomy and independence in language learning (pp. 18-34). London, England: Longman.

[7] Bozpolat, E., \& Gömleksiz, M. N. (2011). An assessment of the 4th and 5th grade primary school students' opinions towards their problem solving skills. Journal of World of Turks, 4 (3) (2012). Retrieved September 15, 2013, from http://www.dieweltdertuerken.org/index.php/ZfWT/article/view/417/gomleks iz_bozpolat

[8] Broady, E., \& Kenning, M. (Eds.) (1996). Promoting learner autonomy in university language teaching. London, England: Association for French Language Studies.

[9] Camilleri, G. (1999). Learner autonomy: The teachers' views. Retrieved January 20, 2013, from http://archive.ecml.at/documents/pubCamilleriG_E.pdf.

[10] Cotterall, S., \& Crabbe, D. (Eds.) (1999). Learner autonomy in language learning: Defining the field and effecting change. Frankfurt a. M., Germany: Peter Lang.

[11] Dickinson, L. (1987). Self-Instruction in language learning. Cambridge: Cambridge University Press.

[12] Dörnyei, Z. (1998). Demotivation in foreign language learning (Paper presented at the TESOL '98 Congress). Seattle, WA, March.

[13] Evrekli, E., Şaşmaz Ören, F., \& İnel, D. (2010). Pre-Service primary teachers' self-efficacy toward the constructivist approach and their opinions about their efficacy levels. Greece, Athens: 12th Annual International Conference on Education (24-27 May). Retrieved September 20, 2013, from https://www.academia.edu/Documents/in/Learner_Autonomy?page=2 .

[14] Field, A. (2005). Discovering statistics using SPSS (2nd ed.). London: Sage.

[15] Gardner, R., C. (2010). Motivation and second language acquisition: The socio-educational model (vol. 10). New York: Peter Lang.

[16] Haseborg, H., E. (2012). Principles of learner autonomy in action: Effects and perceptions in a college-level foreign language class. Retrieved January 20, 2013, from http://search.proquest.com/pqdtft/docview/1095689302/ fulltextPDF/13F37FBF 9D F AEFC915/2?accountid=13014. 
[17] Inomata, K. (2008). Japanese students' autonomy in learning English as a foreign language in out-of-school settings. University of San Francisco.

[18] Johnson, R. K. (Ed.). (1989). The second language curriculum. Cambridge, UK: Cambridge University Press.

[19] Little, D. (2007). Language learning autonomy: Some fundamental considerations revisited. Innovation in Language Learning and Teaching, 1 (1), 14-29.

[20] Little, D., Ridley, J., \& Ushioda, E. (Eds.) (2003). Learner autonomy in the foreign language classroom: Teacher, learner, curriculum and assessment. Dublin, Ireland: Authentik.

[21] Little, D. (1991). Learner autonomy 1: Definitions, issues and problems. Dublin: Authentik.

[22] Nakata, Y. (2011). Teachers' readiness for promoting learner autonomy: A study of Japanese EFL high school teachers. Teaching and Teacher Education, 27 (2011) 900- 910. Retrieved June 15, 2013, from http://www.sciencedirect.com/science/article/pii/S0742051X1100028X.

[23] Nunan, D. 1985. Content familiarity and the perception of textual relationships in second language reading. RELC Journal, 16(1). Retrieved September 20, 2013, from http://rel.sagepub.com/content/16/1/43.

[24] Richards, J.C. (2006). Communicative language teaching today. New York: Cambridge University Press.

[25] Trebbi, T. (2003). Curriculum development and learner autonomy in the foreign language classroom: constraints and possibilities. In D. Little, J. Ridley, \& E. Ushioda (Eds.), Learner autonomy in the foreign language classroom (pp. 166-184). Dublin, Ireland: Authentik.

[26] Yahong, L. (2009). How can I help my students promote learner-Autonomy in English language learning?. Educational Journal of Living Theories, 2(3), 365-398.

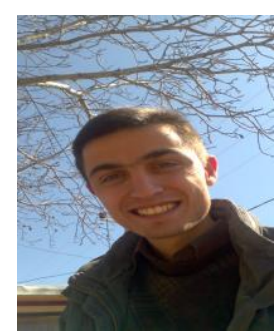

Mehmet Fatih Ürün, Research Assistant at Turkish Military Academy. He received his Bachelor degree, majoring in English, and Minor degree, studying Public Administration and Political Sciences, from the Middle East Technical University in 2009. He completed his MA degree, majoring in Curriculum and Instruction, at the Middle East Technical University in 2013. He is also majoring in Economics as a Bachelor student of distance education at the University of Anatolia, Turkey. His research interests include second/foreign language acquisition through natural approach, language learning autonomy, interdisciplinary methods in language teaching, and culture and language learning.

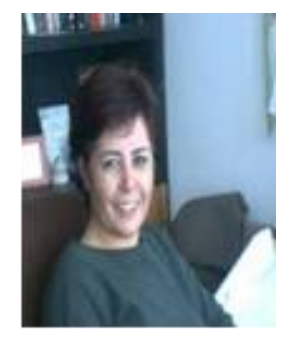

Cennet Engin Demir, Associate professor, holds MA and $\mathrm{PhD}$ degrees in Curriculum and Instruction from Middle East Technical University in Turkey. She has published many articles on different aspects of educational sciences. She has presented numerous articles in national and international conferences. She has also co-authored several books on child education. Her areas of interest include: education in Central Asian Countries, citizenship education, gender and education, social foundations of curriculum, education of disadvantaged, child labor and education, hidden curriculum, and democratic citizenship and human rights education.

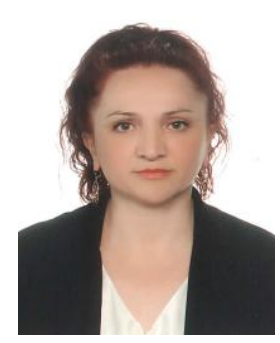

Hanife Akar is an Associated Professor in Curriculum and Instruction. She has earned her Ph.D. degree from Middle East Technical University and works there as an instructor at the Department of Educational Sciences. Her research focuses on teacher development and learning, especially in ELT, classroom management, active citizenship education, moral education, equity, education policy, and internationalization of higher education. Akar is fluent in English, Dutch, and German. 